\title{
Effect of organic minerals and alpha-ketoglutarate in pheasant diet on performance, hatchability and the composition of eggs
}

\author{
MARIAN FLIS, DARIUSZ GUGAŁA \\ Department of Animal Ethology and Wildlife Management, Faculty of Animal Sciences and Bioeconomy, \\ University of Life Sciences in Lublin, Akademicka 13, 20-950 Lublin, Poland
}

Flis M., Gugała D.

Effect of organic minerals and alpha-ketoglutarate in pheasant diet on performance, hatchability and the composition of eggs

\section{Summary}

This study determined the effect of supplementation of the pheasant diet with mineral components (Ca, Fe, $\mathrm{Zn}$ and $\mathrm{Cu}$ ) from organic sources with or without the addition of alpha-ketoglutarate (AKG) on productivity, hatchability parameters, nutrients and mineral content in pheasant eggs. Studies were performed on three groups of laying pheasants, which were kept in aviaries and received a standard mixture (Group I, the control group), a mixture with $\mathrm{Ca}, \mathrm{Fe}, \mathrm{Zn}$, and $\mathrm{Cu}$ glycinates which replaced $50 \%$ of the mineral components in inorganic form (Group II), or a mixture with chelates and a $200 \mathrm{mg}$ alpha-ketoglutarate supplement (Group III). Supplementation of the diet with chelates raised the content level of the mineral components in the whole egg and yolk, mainly the contents of calcium, zinc and iron. The addition of $200 \mathrm{mg}$ of alpha-ketoglutarate to the diet with calcium, zinc, iron and copper chelates of glycine $(50 \%$ of the supplemented elements) resulted in improved laying capacity and rates of reproduction and rearing of chicks, with a slight decrease in the size and weight of eggs. The eggshell was thinner, and the albumen and the Haugh Unit score were higher. Inorganic mineral components can be replaced by glycine chelates at up to $50 \%$, especially with the addition of $200 \mathrm{mg}$ of $\mathrm{AKG}$, in the pheasant diet in commercial breeding.

Keywords: alpha-ketoglutarate, chelates, composition of whole and yolk eggs, hatchability, pheasant hens, supplementation diet

In addition to genetic and environmental factors, poultry feed is an important element of production efficiency. The core purpose of nutrition is to balance meeting the whole need for nutrients with optimising vitamins and minerals. Supplying the needs of poultry for mineral components is through the use of salts (sulphates, carbonates, or phosphates) or oxides. In recent years, there has been a tendency to replace salts with organic sources of mineral components (43). Studies in poultry have shown that even low-level replacement of inorganic minerals with organic forms optimises the growth performance of broilers and laying performance of hens and reduces the pressure on the environment of the excreted minerals. In addition, the use of organic forms reduces antagonism between certain elements, such as $\mathrm{Zn}$ and $\mathrm{Cu}$, and the mineral components from the proteinates have a higher retention rate and better bioavailability than inorganic salts $(1,7,39,48)$.
The use of zinc mineral chelates and phytase supplementation in the diet of broiler chickens increased feed intake and weight gain and, above all, resulted in better feed utilisation. It also increased plasma and bone zinc content and bone mass (2). This knowledge leads to the search for new solutions in chelate production and optimisation of the diet in mineral components, in order to improve the quality and value of breeding indicators and characteristics of farmed birds, including pheasants. Experimental modification of the proportion of mineral components in the diet has been undertaken by replacing inorganic with organic forms $(6,17,24$, $40,47,52)$. The studies to date on the replacement of calcium, iron, zinc and copper salts with glycine chelates have shown a significant impact on pheasant production results. Modification of the diet significantly increased the number of eggs and their hatchability and the survival of chicks (19). Dietary supplementation 
with glycine chelates significantly and beneficially affected the body weight of male pheasants and raised some mechanical bone parameters (15). In turn, the replacement of vitamin D3 with calcitriol (active form of vitamin D-1.25-dihydroxycholecalciferol) resulted in higher phosphorus content and weight gain in males, as well as increases in magnesium and potassium content in muscles (18). These benefits prompted attempts to modify the pheasant diet composition to improve the quantity and quality of eggs, their hatchability and chemical composition, and their nutritional value $(8,16,17,20,24,26,34,42,47)$.

In well-balanced animal diets, in addition to guaranteeing nutrients, various feed additives are used in order to obtain better production results and to improve the health benefits and quality of products. One such additive may be alpha-ketoglutarate (AKG). Studies on the use of this compound in humans and animals have shown its important role in elevating the activity of antioxidant enzymes (32). It has also been shown to have beneficial effects on body weight, gut function, and gut flora composition in mice $(10,49)$. Studies have confirmed that the use of AKG increases the collagen content and mineral density of bones and contributes to an increase in their mechanical resistance $(12,50)$. Dietary supplementation with alpha-ketoglutarate increased the body weight and collagen content of young pigs, thereby improving the geometric and mechanical properties of bones $(28,29)$. Similar results were also obtained in sheep (21). A beneficial effect of dietary supplementation of pigs with $\mathrm{AKG}$ has also been shown in the aspects of both intestinal flora and oxidative stress, but this did not improve the production results in this species (31). Studies conducted on turkeys indicated a positive effect of dietary supplementation of $\mathrm{AKG}$ on the development of the bone system (44). The results of studies conducted in laying hens showed that a $1 \%$ addition of $A K G$ during the laying period improved the mechanical parameters of the bones by increasing the synthesis of collagen and lowered the cholesterol content in the muscles (46).
It can be argued by extension that the use of mineral chelates and alpha-ketoglutarate may change the morphometric characteristics, nutritional value and mineral composition of eggs.

The aim of the investigation was to evaluate the effect of supplementation of the pheasant diet with mineral components $(\mathrm{Ca}, \mathrm{Fe}, \mathrm{Zn}$ and $\mathrm{Cu})$ from organic sources with or without the addition of $\mathrm{AKG}$ on bird productivity, hatchability parameters, and nutrients and mineral content in pheasant eggs.

\section{Material and methods}

Ethical approval. The experimental procedures used throughout this study were approved by the Local Ethics Committee on Animal Experimentation of the University of Life Sciences in Lublin, Poland (resolution no. 22/2016 of 13 May 2016).

Feed. Calcium, iron, zinc and copper formulated as salts and glycine chelates were introduced into a mineral and vitamin premix which did not contain these minerals. The $\mathrm{Ca}$, $\mathrm{Fe}, \mathrm{Zn}$, and $\mathrm{Cu}$ requirement in the feed mixtures was based on the dietary recommendations of the National Research Council (1994). The mixture was composed independently on the basis of ingredients from the AGROPOL Concentrates and Mixtures Production Plant in Motycz. Glystar Forte chelates produced by Arkop (Bukowno, Poland) containing $20 \% \mathrm{Ca}$ and $46 \%$ glycine, $16 \% \mathrm{Fe}$ and $42 \%$ glycine, $16 \% \mathrm{Zn}$ and $36 \%$ glycine, and $16 \% \mathrm{Cu}$ and $37 \%$ glycine were used in the experiment (Tab. 1). All the feed components were mixed and pelleted $\left(0.5 \mathrm{~mm}\right.$ diameter) at $60^{\circ} \mathrm{C}$.

Animals. The experimental animals were pheasant hens (Phasianus colchicus) in their first reproductive season, kept on a commercial farm in three cages (Tab. 1). The study was carried out on 21 healthy female and 3 healthy male pheasants (all 12 weeks old) from the breeding flock of the participating farm. There were 7 hens and 1 rooster in each group. The birds were kept outdoors in cages $8.5 \mathrm{~m}$ long $\times 5.0 \mathrm{~m}$ wide $\times 3.5 \mathrm{~m}$ high. Each cage was equipped with two nipple drinkers supplying water ad libitum and an automatic feeder $40 \mathrm{~cm}$ long, i.e. offering $4.0 \mathrm{~cm}$ of feeder edge per bird. A natural mating system of one male and seven females was used in each cage.

Tab. 1. Composition of mineral and alpha-ketoglutarate addition in $1 \mathrm{~kg}$ of experimental diets

\begin{tabular}{|c|c|c|c|c|}
\hline \multirow{2}{*}{ Diet ingredients } & \multirow{2}{*}{$\begin{array}{c}\text { NRC Requirement, } \\
1994\end{array}$} & \multicolumn{3}{|c|}{ Diet supplementation } \\
\hline & & Group I - Control & Group II - Chelates & Group III - Chelates + AKG \\
\hline Calcium carbonate ( $35 \% \mathrm{Ca}), \mathrm{g}$ & \multirow{2}{*}{25} & $25(100 \%)^{1)}$ & $12.5(50 \%)$ & $12.5(50 \%)$ \\
\hline Calcium glycine ${ }^{2)}(20 \%$ Ca), g & & - & $12.5(50 \%)$ & $12.5(50 \%)$ \\
\hline Copper sulphate pentahydrate $(25 \% \mathrm{Cu}), \mathrm{mg}$ & \multirow{2}{*}{5} & $5(100 \%)$ & $2.5(50 \%)$ & $2.5(50 \%)$ \\
\hline Copper glycine $(16 \% \mathrm{Cu}), \mathrm{mg}$ & & - & $2.5(50 \%)$ & $2.5(50 \%)$ \\
\hline Ferrous sulphate heptahydrate $(20 \% \mathrm{Fe}), \mathrm{mg}$ & \multirow{2}{*}{60} & $60(100 \%)$ & $30(50 \%)$ & $30(50 \%)$ \\
\hline Ferrous glycine ( $16 \% \mathrm{Fe}), \mathrm{mg}$ & & - & $30(50 \%)$ & $30(50 \%)$ \\
\hline Zinc sulphate heptahydrate (22\% Zn), mg & \multirow{2}{*}{50} & $50(100 \%)$ & $25(50 \%)$ & $25(50 \%)$ \\
\hline Zinc glycine (16\% Zn), mg & & - & $25(50 \%)$ & $25(50 \%)$ \\
\hline Alpha-ketoglutarate, mg & & - & - & 200 \\
\hline
\end{tabular}

Explantions: ${ }^{1)}$ percent provision of nutritional requirement for the minerals (NRC, 1994); ${ }^{2)}$ glycinate chelate: Glystar Forte Ca, Fe, $\mathrm{Zn}$ and $\mathrm{Cu}$ (Arkop, Poland) 
All the pheasants were maintained ad libitum on the regular complete diets for the breeding flock of the participating farm. The ingredient and chemical compositions of the experimental basic diets during the rearing period between 5 and 16 weeks of life and during the laying period are presented in Table 2. The nutritional value of the breeder diet was determined according to the National Research Council (36). The feed was provided to the breeding pheasants during the 4 weeks before the laying period.

Tab. 2. Ingredients $\left(\mathrm{g} \mathrm{kg}^{-1}\right)$ and nutritional value of pheasant hen basal diet

\begin{tabular}{|c|c|c|}
\hline Components & Rearing (5-16 weeks) & Hens \\
\hline Corn & 272.0 & 291.5 \\
\hline Wheat & 100.0 & 252.0 \\
\hline Soybean meal & 280.0 & 220.0 \\
\hline Garden pea & 50.0 & 50.0 \\
\hline Fish meal & 20.0 & 0.00 \\
\hline Linseed & 40.0 & 40.0 \\
\hline Sunflower meal & 80.0 & 80.0 \\
\hline Sorghum & 30.0 & 50.0 \\
\hline Soya oil & 50.0 & 0.0 \\
\hline Salt & 3.0 & 3.0 \\
\hline Mineral-vitamin premix & 2.5 & 2.5 \\
\hline DL-methionine & 0.7 & 0.3 \\
\hline L-lysine chloride & 0.9 & 0.7 \\
\hline \multicolumn{3}{|l|}{ Analysed value: } \\
\hline Dry matter & 895.4 & 894.8 \\
\hline Crude protein & 232.7 & 189.6 \\
\hline Crude fat & 51.2 & 33.8 \\
\hline Crude fibre & 39.8 & 49.6 \\
\hline Crude ash & 69.2 & 69.1 \\
\hline Calcium & 8.2 & 25.9 \\
\hline Total phosphorus & 6.5 & 6.9 \\
\hline Iron, $\mathrm{mg} \mathrm{kg}^{-1}$ & 72.1 & 104.1 \\
\hline Zinc, $\mathrm{mg} \mathrm{kg}^{-1}$ & 64.2 & 73.4 \\
\hline Copper, mg kg-1 & 5.3 & 5.9 \\
\hline Lysine & 13.8 & 11.2 \\
\hline Methionine & 4.8 & 3.5 \\
\hline Palmitic acid (16:0) & 4.21 & 4.13 \\
\hline Stearic acid (18:0) & 0.79 & 0.72 \\
\hline Oleic acid $(18: 1, \omega-9)$ & 7.24 & 6.31 \\
\hline Linoleic acid $(18: 2, \omega-6)$ & 25.41 & 16.05 \\
\hline Linolenic acid, $(18: 3, \omega-3)$ & 2.11 & 1.13 \\
\hline AMEn, MJ kg-1 * & 12.05 & 10.56 \\
\hline
\end{tabular}

Explantions: the mineral-vitamin premix in the control group provided $60 \mathrm{mg} \mathrm{Mn,} 1.2 \mathrm{mg}$ I, $50 \mathrm{mg}$ Fe, $40 \mathrm{mg} \mathrm{Zn,} 5 \mathrm{mg} \mathrm{Cu}, 0.2 \mathrm{mg}$ Se, 10000 IU vit. A, $2500 \mathrm{IU}$ vit. $\mathrm{D}_{3}, 50 \mathrm{mg}$ vit. E, $2 \mathrm{mg}$ vit. $\mathrm{K}_{3}$, $1.5 \mathrm{mg}$ vit. $\mathrm{B}_{1}, 4.5 \mathrm{mg}$ vit. $\mathrm{B}_{2}, 3 \mathrm{mg}$ vit. $\mathrm{B}_{6}, 0.015 \mathrm{mg} \mathrm{B} \mathrm{B}_{12}, 0.1 \mathrm{mg}$ biotin, $0.8 \mathrm{mg}$ folic acid, $20 \mathrm{mg}$ nicotinic acid, $12 \mathrm{mg}$ pantothenic acid, and $300 \mathrm{mg}$ choline per kg. * AMEn - metabolizable energy at zero nitrogen balance was calculated by the equations of Fisher and $\mathrm{McNab}$ (1987).
Eggs. Eggs obtained at the culmination of the egg production period were used for the experiment. The collected pheasant eggs were placed in trays and kept at $18^{\circ} \mathrm{C}$ for 7 days, which is a storage period which does not impinge on egg quality or incubation success $(8,11)$.

The weights of the eggs were determined on electronic scales accurate to $1 \mathrm{~g}$, and the lengths and widths of the eggs were measured with electronic slide callipers accurate to $0.1 \mathrm{~mm}$. The shell area was calculated with the equation for chicken eggs of Paganelli et al. (38):

$$
\mathrm{Ps}=4.835 \times \mathrm{W}^{0.662}
$$

where $\mathrm{W}$ is egg weight.

The shell thickness was calculated with the formula derived by Ar et al. (4):

$$
\mathrm{L}=54.06 \times \mathrm{W}^{0.448} \text {. }
$$

The shape index was determined as the ratio of the width of the egg to its length expressed in \%.

After the preliminary measurements, 21 eggs from each group were broken individually onto a flat surface and left for 5 minutes, after which time the height of the protein was measured using a micrometer screw gauge placed on a tripod. The measurement was made at three points $1 \mathrm{~cm}$ from the edge of the yolk, and the average of the three measurements was the value used in operations. Haugh Unit (HU) values were calculated using the following formula (22):

$$
\mathrm{HU}=100 \times \log (\mathrm{H}+7.57-1.7) \times \mathrm{W}^{0.37}
$$

where $\mathrm{H}$ is albumen height in millimetres and $\mathrm{W}$ is egg weight in grams.

The yolks were separated from these eggs and combined. In addition, whole eggs ( 21 from each group) were broken and mixed, and the samples were frozen at $-20^{\circ} \mathrm{C}$ until laboratory analysis. Pooled samples for analysis were obtained from 3 eggs $(n=7)$. From the remaining properly formed eggs, 120 were randomly selected from each experimental group and incubated.

The assessment of fertilised eggs and ascertainment that there were unfertilised eggs was carried out on days 7 and 21 of incubation. At the end of the incubation period, the eggs were hatched. The hatchability was calculated for eggs incubated to the hatching stage as was the percentage of eggs incubated and hatched from which live chicks were produced. Survival percentages for the number of chicks hatched on day 7 and day 14 of rearing were also determined.

Analytical procedures. The chemical compositions of the basal and experimental diets were analysed for their dry matter, crude protein, crude fibre, crude fat, crude ash and amino acids according to AOAC procedures (3). Nutrient contents in eggs and yolk were also analysed for their dry matter, crude protein and crude ash, likewise according to AOAC procedures (3).

The contents of $\mathrm{Ca}, \mathrm{Fe}, \mathrm{Zn}, \mathrm{Cu}, \mathrm{Mg}, \mathrm{K}$, and $\mathrm{Na}$ in the feed, whole eggs and yolk samples were determined using the AAS flame technique in a Unicam 939 apparatus (AA Spectrometer Unicam, Shimadzu Corp., Tokyo, Japan) after incineration at $550^{\circ} \mathrm{C}$, according to the methods adopted by the AOAC (3).

The total phosphorus content in the feed, eggs and yolks was identified colorimetrically (14) with a Helios Alpha 
UV-Vis apparatus (Spectronic Unicam, Leeds, United Kingdom).

Statistical analysis. The obtained data were subjected to statistical analysis in Statistica 10.0 (StatSoft, Tulsa, OK, USA). Two-factor analysis of variance (ANOVA) was used according to the following model:

where:

$$
Y_{i j}=\mu+a_{i}+e_{i j}
$$

$\mathrm{y}_{\mathrm{ij}}$ - is the observed dependent variable,

$\mu-$ is the overall mean,

$\mathrm{a}_{\mathrm{i}}$ - is the mean effect of $\mathrm{i}^{\text {th }}$,

$\mathrm{e}_{\mathrm{ij}}-\mathrm{is}$ random error.

Tukey's test was used to determine the significance of the differences between the dietary averages of each feed group, and the relationships were found to be significant at $\mathrm{P} \leq 0.05$.

\section{Results and discussion}

Dietary supplementation with chelates and chelates in combination with $\mathrm{AKG}$ resulted in a significant $(\mathrm{P} \leq 0.05)$ increase in the laying performance of pheasant hens, while reducing the number of defective (unfertilised) eggs (Tab. 3). There was a slight reduction in egg size and thus in their weight, but these differences

Tab. 3. Egg weight and morphometric characteristics

\begin{tabular}{|c|c|c|c|c|c|}
\hline \multirow[b]{2}{*}{ Characteristics of eggs } & \multicolumn{3}{|c|}{ Treatment } & \multirow[b]{2}{*}{ SEM } & \multirow[b]{2}{*}{$P$ values } \\
\hline & $\begin{array}{c}\text { Group I } \\
\text { Control (C) }\end{array}$ & $\begin{array}{l}\text { Group II } \\
\text { Chelates }\end{array}$ & $\begin{array}{c}\text { Group III } \\
\text { Chelates + AKG }\end{array}$ & & \\
\hline Total number of eggs & $335^{\mathrm{a}}$ & $368^{b}$ & $371^{b}$ & 12.5 & 0.041 \\
\hline Deficient eggs, $\%$ & 6.35 & 4.02 & 3.98 & 2.05 & 0.058 \\
\hline Egg weight, g & 33.7 & 33.4 & 32.9 & 1.38 & 0.096 \\
\hline Egg length, mm & 47.3 & 47.2 & 47.2 & 0.34 & 0.415 \\
\hline Egg width, mm & 38.4 & 38.2 & 38.0 & 0.23 & 0.264 \\
\hline Egg shape index, \% & 82.0 & 81.0 & 81.0 & 0.50 & 0.252 \\
\hline Eggshell area, $\mathrm{cm}^{2}$ & 49.62 & 49.33 & 48.84 & 0.92 & 0.287 \\
\hline Eggshell thickness $\mu \mathrm{m}$ & 261.3 & 260.3 & 258.6 & 5.68 & 0.312 \\
\hline Height of the egg white (mm) & 4.00 & 3.98 & 4.12 & 0.06 & 0.216 \\
\hline Haugh unit (HU) & 72.8 & 72.9 & 74.3 & 1.04 & 0.102 \\
\hline
\end{tabular}

Explantions: $\mathrm{a}, \mathrm{b}, \mathrm{c}-$ values with different superscript letters differ significantly at $\mathrm{P} \leq 0.05$.

Tab. 4. Hatchability results

\begin{tabular}{|l|c|c|c|c|c|}
\hline \multicolumn{1}{|c|}{ Incubation and rearing } & \multicolumn{2}{c|}{$\begin{array}{c}\text { Treatment } \\
\text { Group II } \\
\text { Control (C) }\end{array}$} & $\begin{array}{c}\text { Group III } \\
\text { Chelates }\end{array}$ & SEM & P values \\
\hline Chelates + AKG & 120 & 120 & 120 & 0.0 & 1.000 \\
\hline Eggs inserted in the incubator & 88.0 & 91.0 & 92.0 & 2.5 & 0.053 \\
\hline Fertilised eggs, $7^{\text {th }}$ day of incubation, \% of laid eggs & $65.0^{\mathrm{a}}$ & $68.0^{\mathrm{ab}}$ & $74.0^{\mathrm{b}}$ & 3.5 & 0.041 \\
\hline Eggs laid in the hatcher, \% of incubated eggs & $60.0^{\mathrm{a}}$ & $61.0^{\mathrm{a}}$ & $68.0^{\mathrm{b}}$ & 2.5 & 0.043 \\
\hline Hatchlings, \% of incubated eggs & $48.4^{\mathrm{a}}$ & $48.6^{\mathrm{a}}$ & $54.7^{\mathrm{b}}$ & 2.7 & 0.042 \\
\hline Hatchlings, \% of eggs from the hatcher & $72.4^{\mathrm{a}}$ & $80.1^{\mathrm{b}}$ & $92.1^{\mathrm{c}}$ & 3.2 & 0.024 \\
\hline 7-day-old hatchlings, \% of all hatched & $80.2^{\mathrm{a}}$ & $86.7^{\mathrm{b}}$ & $94.2^{\mathrm{c}}$ & 3.4 & 0.029 \\
\hline 14-day-old hatchlings, \% of all hatched & $69.8^{\mathrm{a}}$ & $77.5^{\mathrm{b}}$ & $85.4^{\mathrm{c}}$ & 2.6 & 0.026 \\
\hline
\end{tabular}

Explantions: as in Tab. 3 were not significant. The egg shape index was lower, and was the same in both experimental groups. The surface area and thickness of the shell also decreased, but the differences from the control group were insignificant. The eggs from the chelated feed group had a lower albumen height resulting in a slightly higher HU score, while those given chelated feed supplemented with AKG had higher albumen resulting in the highest HU score for this group. These differences were not statistically significant.

The eggs from the group fed the chelated diet supplemented with AKG had the highest fertilisation rates measured on days 7 and 21 of incubation (Tab. 4) and these rates differed statistically significantly. This group had $8 \%$ more eggs suitable to put on the hatcher compared to the control group. The proportion which hatched also peaked in this group, and for eggs laid on the hatcher it was almost $20 \%$ higher than that of the control group. Successful chick rearing was higher in both the group of birds supplemented with chelates and the group additionally supplemented with $\mathrm{AKG}$, with the latter group achieving the highest values on both days 7 and day 14 of rearing.

The applied dietary supplementation produced an increase in the content of dry egg mass, crude protein and crude ash (Tab. 5). Significantly higher protein content was found in the dietary groups with the addition of chelates and chelates with AKG compared to the control group, and the experimental groups did not differ significantly from each other. Both experimental groups showed a statistically significantly higher content of raw ash than the control group. There was also a significant difference in the fat content between the group in which the feed with $\mathrm{AKG}$ was added and the control group and the group without the addition of $\mathrm{AKG}$.

The chemical composition of the egg yolk was less diverse between groups. The highest content of dry matter and crude protein was found in the group with the dual dietary supplementation, and birds in this group had the lowest yolk fat content. However, these differences were not statistically significant. The yolks of the experimental groups' eggs were 
Tab. 5. Chemical composition of whole eggs and yolk of pheasant (\%)

\begin{tabular}{|l|c|c|c|c|c|c|}
\hline \multicolumn{1}{|c|}{ Components } & $\begin{array}{c}\text { Treatment } \\
\text { Group I } \\
\text { Control (C) }\end{array}$ & $\begin{array}{c}\text { Group II } \\
\text { Chelates }\end{array}$ & $\begin{array}{c}\text { Group III } \\
\text { Chelates + AKG }\end{array}$ & SEM & P values \\
\hline Egg: & 24.18 & 24.34 & 24.28 & 0.74 & 0.126 \\
\hline - dry matter & $12.15^{\mathrm{a}}$ & $12.9^{\mathrm{ab}}$ & $12.31^{\mathrm{b}}$ & 0.13 & 0.041 \\
\hline - crude protein & $10.23^{\mathrm{a}}$ & $10.20^{\mathrm{a}}$ & $10.02^{\mathrm{b}}$ & 0.11 & 0.034 \\
- crude fat & $1.12^{\mathrm{a}}$ & $1.29^{\mathrm{b}}$ & $1.31^{\mathrm{b}}$ & 0.07 & 0.025 \\
- crude ash & 0.68 & 0.66 & 0.64 & 0.05 & 0.118 \\
- nitrogen-free extract & & & & & \\
\hline Yolk: & 47.02 & 46.98 & 47.06 & 0.42 & 0.192 \\
\hline - dry matter & 16.22 & 16.24 & 16.35 & 0.18 & 0.098 \\
- crude protein & 25.86 & $25.81^{2}$ & 25.65 & 0.21 & 0.103 \\
\hline - crude fat & $1.45^{\mathrm{a}}$ & $1.51^{\mathrm{ab}}$ & $1.59^{\mathrm{b}}$ & 0.09 & 0.044 \\
\hline - crude ash & 3.49 & 3.42 & 3.47 & 0.07 & 0.138 \\
\hline - nitrogen-free extract & & & & & \\
\hline
\end{tabular}

Explantions: $\mathrm{a}, \mathrm{b}$ - values with different superscript letters differ significantly at $\mathrm{P} \leq 0.05$.

Tab. 6. Mineral content of whole eggs and yolk of pheasant hens

\begin{tabular}{|c|c|c|c|c|c|}
\hline \multirow[b]{2}{*}{ Components } & \multicolumn{3}{|c|}{ Treatment } & \multirow[b]{2}{*}{ SEM } & \multirow[b]{2}{*}{$P$ values } \\
\hline & $\begin{array}{l}\text { Group I } \\
\text { Control (C) }\end{array}$ & $\begin{array}{l}\text { Group II } \\
\text { Chelates }\end{array}$ & $\begin{array}{c}\text { Group III } \\
\text { Chelates + AKG }\end{array}$ & & \\
\hline \multicolumn{6}{|l|}{ Egg: } \\
\hline Calcium, $\mathbf{g ~ k g - 1}$ DM & $2.69^{b}$ & $2.84^{a}$ & $2.86^{\mathrm{a}}$ & 0.15 & 0.042 \\
\hline Phosphorus, $\mathrm{g} \mathrm{kg}^{-1} \mathrm{DM}$ & 9.14 & 9.16 & 9.18 & 0.78 & 0.258 \\
\hline Magnesium, $\mathrm{g} \mathrm{kg}^{-1} \mathrm{DM}$ & 0.70 & 0.71 & 0.71 & 0.02 & 0.448 \\
\hline Potassium, $\mathrm{g} \mathrm{kg}^{-1} \mathrm{DM}$ & 9.02 & 9.12 & 9.15 & 0.43 & 0.292 \\
\hline Sodium, $\mathrm{g} \mathrm{kg}^{-1} \mathrm{DM}$ & 6.04 & 6.08 & 6.07 & 0.04 & 0.293 \\
\hline Iron, $\mathrm{mg} \mathrm{kg}^{-1} \mathrm{DM}$ & $160.9^{b}$ & $172.3^{a}$ & $174.1^{\mathrm{a}}$ & 5.58 & 0.043 \\
\hline Zinc, $\mathrm{mg} \mathrm{kg}^{-1} \mathrm{DM}$ & $58.31^{\mathrm{b}}$ & $69.35^{\mathrm{a}}$ & $70.14^{a}$ & 3.86 & 0.028 \\
\hline Copper, mg kg-1 DM & 2.23 & 2.33 & 2.34 & 0.06 & 0.063 \\
\hline \multicolumn{6}{|l|}{ Yolk: } \\
\hline Calcium, $\mathrm{g} \mathrm{kg}^{-1} \mathrm{DM}$ & $3.45^{\mathrm{b}}$ & $3.70^{\mathrm{a}}$ & $3.79^{a}$ & 0.34 & 0.043 \\
\hline Phosphorus, $\mathrm{g} \mathrm{kg}^{-1} \mathrm{DM}$ & 11.08 & 11.18 & 11.21 & 0.82 & 0.226 \\
\hline Magnesium, $\mathbf{g ~ k g}^{-1} \mathrm{DM}$ & 0.329 & 0.330 & 0.331 & 0.02 & 0.441 \\
\hline Potassium, $\mathrm{g} \mathrm{kg}^{-1} \mathrm{DM}$ & 2.52 & 2.56 & 2.59 & 0.39 & 0.295 \\
\hline Sodium, $\mathrm{g} \mathrm{kg}^{-1} \mathrm{DM}$ & 1.23 & 1.21 & 1.22 & 0.02 & 0.289 \\
\hline Iron, $\mathrm{mg} \mathrm{kg}^{-1} \mathrm{DM}$ & $132.9^{c}$ & $151.9^{b}$ & $172.1^{a}$ & 5.52 & 0.035 \\
\hline Zinc, $\mathrm{mg} \mathrm{kg}^{-1} \mathrm{DM}$ & $59.12^{b}$ & $73.44^{\mathrm{a}}$ & $74.12^{\mathrm{a}}$ & 3.86 & 0.023 \\
\hline Copper, $\mathrm{mg} \mathrm{kg}^{-1} \mathrm{DM}$ & 1.96 & 2.23 & 2.25 & 0.05 & 0.056 \\
\hline
\end{tabular}

Explantions: $a, b$ - values with different superscript letters differ significantly at $\mathrm{P} \leq 0.05 ; \mathrm{DM}-$ dry mater.

characterised by a statistically significantly higher content of raw ash compared to those of the control group.

Chelates both alone and with AKG as improvers of the birds' diet increased the mineral content of eggs (Tab. 6). A higher content of individual elements was noted both in the birds in the group supplemented with chelates, and in the diet supplemented with chelates in combination with the addition of $\alpha$-ketoglutarate. The differences in calcium, iron and zinc contents compared to these contents in the control group were statistically significant. In the group of birds receiving a diet offering $\mathrm{AKG}$ and chelates, the mineral content was slightly higher still, but the mean values of these element contents differed statistically significantly from those of the control group only for calcium, iron and zinc.

The dietary supplementation of these pheasants changed the mineral composition of the yolks of their eggs. In both experimental groups, a higher content of mineral components in the yolk was noted, with the exception of sodium. Statistically significant differences were found between the experimental groups and the control group for calcium, iron and zinc levels. No such differences were observed between the experimental groups. There were also no significant differences for the studied traits in yolk depending on the season.

One of the most important factors in the reproduction and rearing of birds is their nutrition. Previous studies on pheasant feeding optimisation on closed farms have focused mainly on balancing the energy value, appropriate protein level and amino acid profile $(17,30,41)$. It was shown that the use of a diet with a $4 \%$ reduction in the level of protein compared to the control group decreased the size and weight of eggs, and they typically had a smaller surface area and thinner and weaker shells (27). However, an increase in the level of raw protein to $18 \%$ in the pheasant diet significantly amelioratively affected the laying performance, egg mass and hatchability (47).

The addition of bioalginates to the diet of pheasant chicks significantly enhanced the growth rate of and gained body weight for the birds. At the same time, birds fed on lower protein and higher energy content diets made higher gains, regardless of whether a bioalginate supplement was used (20).

Until recently, much less attention had been paid to investigation of the influence of quantity and quality of mineral components on production results in breeding operations and meat and egg quality $(40,43)$. In recent years however, alternative sources of supplementation with mineral components have been increasingly sought, and operators of closed farms of pheasants are among the seekers, the pheasant use being immaterial. Studies on mineral components' effects in diets, including studies on the substitution of 
inorganic forms with organic ones, are being conducted more and more widely $(6,17,19,24,47,48,52)$.

Studies conducted in laying hens on the effects of the addition of zinc, copper, and manganese mineral chelates showed their effect on egg mass and shell thickness, but not on production results (6), while the addition of calcium chelate to the diet of pheasants significantly raised egg production and increased bone content, which may be relevant for its subsequent synthesis in egg shells (24).

The results of the present study obtained in the control and experimental groups regarding the size and weight of eggs were slightly higher than those presented in the studies of Nowaczewski et al. (35) and Kirikçi et al. (25), where smaller egg size and weight were found. A slightly higher egg mass was observed in the studies of Mangiagalli et al. (33). The studies of Ozbey et al. (37) yielded similar results for egg weights to those obtained in laying hens receiving a chelated diet in combination with $\alpha$-ketoglutarate.

Previous studies by the present authors (19) on the replacement of calcium, iron, zinc and copper salts with glycine chelates in different proportions in pheasant feed showed such replacements to have a significant impact on production results. The modification of the diet significantly increased the number of eggs laid while reducing their size and thus their weight. Better hatchability and survival of chicks were also found (19), and the best results were obtained with 50\% salt supplementation with chelates. In addition, glycine chelates contributed to an increase in bone density and thus an increase in their resistance to mechanical damage (15).

Based on the conclusion of previous results that the optimal level of supplementation may be $50 \%$ glycinate in the diet of laying pheasants (19), this experiment showed that supplementation with AKG improved the laying performance while reducing the size and weight of eggs. The eggshell was thinner, and the albumen and the HU scores were higher. Reproduction parameters, i.e. the number of fertilised eggs on each assessment day and the hatchability and rearing rates also improved. There was also an increase in the content of raw protein and raw ash as well as a decrease in the fat content of both the yolk and the whole egg. Differences in egg weight and chemical composition can have a significant impact on pheasant productivity, as confirmed by Ashraf et al. (5). Similar results were reported by Ipek and Dikme (23), who showed a significant relationship between egg weight and post-hatching chick weight and weight gain during rearing with no effect on bird mortality. There was also a negative correlation between the number of eggs laid per season and the weight of chicks at hatching and a positive correlation between the weight of eggs and the weight of chicks (37). In addition, research by Yamak et al. (51) reported that eggshell thickness had a significant impact on the hatching rate of pheasant chicks. In our own studies, there were no statistically significant differences between the experimental and control groups in the thickness of the egg shell, but significantly higher rates of hatchability and rearing of chicks were observed in the experimental groups with chelates and chelates with AKG.

Alpha-ketoglutarate is a molecule involved in many metabolic and cellular pathways. It acts as an energy donor and a precursor in the production of amino acids and is a regulator of epigenetic processes. It is also a key source of glutamate and glutamine, which stimulate protein synthesis and inhibit protein degradation in muscles. Dietary supplementation with alpha-ketoglutarate, a key molecule of tricarboxylic acid, showed beneficial effects on gut function in both experimental animals $(10,49)$ and farm animals $(9)$. Studies of dietary supplementation with alpha-ketoglutarate in turkeys indicated an increase in the synthesis of certain amino acids, which resulted in greater bone mineral density and thus made bones significantly stronger mechanically (45). Experiments on the effects of dietary supplementation with alpha-ketoglutarate in laying hens showed increased collagen synthesis in the bones but reduced cholesterol content in the pectoral muscles, without there being any effect on feed intake or weight gain (46).

The addition of $200 \mathrm{mg}$ of AKG to $1 \mathrm{~kg}$ of diet with calcium, zinc, iron and copper chelates of glycine $(50 \%$ of the supplemented elements) resulted in improved laying performance and rates of reproduction and rearing of chicks, while reducing the size and weight of eggs. The eggshell was thinner, and the albumen and the HU score were higher. Supplementation of the diet with AKG also brought about an increase in mineral components in the whole egg and yolk, mainly calcium, iron and zinc, the levels of which were statistically significantly higher than those in the control group $(\mathrm{P} \leq 0.05)$. In the experimental groups, eggs were characterised by contents of raw protein and raw ash higher by statistically significant differences $(\mathrm{P} \leq 0.05)$, and a lower content of fat in both the yolk and the whole egg.

The supplementation of calcium, iron, zinc, and copper chelates and AKG in the diet of laying pheasants had a significant augmentative impact on productivity and on the chemical composition of eggs. Replacement of $50 \%$ of mineral salts with glycine chelates, especially with the addition of $200 \mathrm{mg} \mathrm{AKG}$ in the diet, can be implemented with breeding pheasants. This practice also contributed to improving the nutritional quality of pheasant eggs, which may be a desirable part of the human diet in comparison to eggs of other birds.

\section{References}

1. Ao T., Pierce J.: The replacement of inorganic mineral salts with mineral proteinates in poultry diets. World's Poul. Sci. J. 2013, 69, 5-16, doi: 10.1017/ S0043933913000019.

2. Ao T., Pierce J. L., Pescatore A. J., Cantor A. H., Dawson K. A. Ford M. J. Shafer B. L.: Effect of organic zinc and phytase supplementation in a maizesoybean meal diet on the performance and tissue zinc content of broiler chicks. Brit. Poul. Sci. 2007, 48, 690-695, doi: 10.1080/00071660701694072.

3. AOAC (Association of Official Analytical Chemists). Official Methods of Analysis of AOAC International, $18^{\text {th }}$ Ed., Rev. 3, edited by W. Horowitz and G. W. Latimer, Jr., Gaithersburg: AOAC International 2010.

4. Ar A., Rahn H., Paganelli C. V.: The avian egg: mass and strength. Condor 1979, 81, 331-337, doi: 10.2307/1366955.

5. Ashraf S., Javid A., Ashraf M., Akram M., Malik S., Irfan S., Altaf M.: Influence of egg weight on egg quality parameters and growth traits in ring necked 
pheasants (Phasianus colchicus) in captivity. J. Anim. Plant Sci. 2016, 26, 331-338.

6. Bai S., Jin G., Li D., Ding X., Wang J., Zhang K., Zeng O., Ji F., Zhao J.: Dietary organic trace minerals level influences eggshell quality and minerals retention in hens. Ann. Anim. Sci. 2017, 17, 503-515, doi: 10.1515/aoas-2016-0074.

7. Baloch Z., Yasmeen N., Pasha T. N., Ahmad A., Taj M. K., Khosa A. M. Maghazani I. B., Bangulzai N., Ahmad I., Hua Y. S.: Effect of replacing inorganic with organic trace minerals on growth performance, carcass characteristics and chemical composition of broiler thigh meat. Afr. J. Agric. Res. 2017, 12 , 1570-1575, doi: 10.5897/AJAR2016.12104.

8. Caglayan T., Alasahan S., Çetin O., Kirikçi K., Günlü A.: Effects of egg weight and length of storage period on chick weight and hatchability performance of pheasants (Phasianus colchicus). J. Food Agric. Environ. 2010, 8, 407-410.

9. Chen J., Kang B., Jiang Q., Han M., Zhao Y., Long L., Fu C., Yao K.: Alphaketoglutarate in low-protein diets for growing pigs: effects on cecal microbia communities and parameters of microbial metabolism. Front. Microbiol. 2018, 9, 1057, doi: 10.3389/fmicb.2018.01057.

10. Chen S., Bin P., Ren W., Gao W., Liu G., Yin J., Duan J., Li Y., Yao K., Huang R., Tan B., Yinc Y.: Alpha-ketoglutarate (AKG) lowers body weight and affects intestinal innate immunity through influencing intestinal microbiota. Oncotarget. 2017, 8, 38184-38192, doi:10.18632/oncotarget.17132.

11. Demirel Ş., Kirikçi K.: Effect of different egg storage times on some egg quality characteristics and hatchability of pheasants (Phasianus colchicus). Poultry Sci. 2009, 88, 440-444, doi:10.3382/ps.2008-00131.

12. Filip R.: Alpha-ketoglutaric acid and bone tissue metabolism. Med. Sci. Technol. 2007, 48, 3-9.

13. Fisher $C$., McNab J.: Techniques for determining the metabolisable energy (ME) content of poultry feed, [in:] Haresign W., Cole D. J. A. (eds): Recent Advances in Animal Nutrition, London Butterworths 1987, 3-18.

14. Fiske C. H., Subbarow Y: The colorimetric determination of phosphorous. J. Biol. Chem. 1925, 66, 375-400, doi: 10.1016/S0021-9258(18)84756-1.

15. Flis M., Gugała D., Muszyński S., Dobrowolski P., Kwiecień M., Grela E. R., Tomaszewska E.: The influence of the partial replacing of inorganic salts of calcium, zinc, iron, and copper with amino acid complexes on bone development in male pheasants from aviary breeding. Animals 2019, 9, 237, doi: 10.3390 ani9050237.

16. Franco D., Lorenzo J. M.: Meat quality nutritional composition of pheasants (Phasianus colchicus) reared in an extensive system. Brit. Poult. Sci. 2013, 54, 594-602, doi: 10.1080/00071668.2013.828195.

17. Gašparovič M., Hrnčár C., Galik B.: The effect of feed additives in pheasants fattening: a review. J. Centr. Europ. Agricul. 2017, 18, 749-761, doi: 10.5513/ JCEA01/18.4.1953.

18. Grela E. R., Gugata D., Flis M.: Influence of partial replacement of some inorganic minerals with glycine complex and vitamin $\mathrm{D}_{3}$ source on performance, slaughter traits, sensory and physico-chemical characteristics of pheasant muscles (Phasianus colchicus L.) depending on gender. Ann. Anim. Sci. 2021, 21, 245-265, doi: 10.2478/aoas-2020-0055.

19. Gugata D., Flis M., Grela E. R.: The effect of zinc, iron, calcium, and coppe from organic sources in pheasant diet on the performance, hatching, minerals, and fatty acid composition of eggs. Poult. Sci. 2019, 98, 4640-4647, doi: 10.3382/ PS/pez162.

20. Hanzal V., Divišová M., Murawska D., Janiszewski P.: The effect of dietary bio-alginate supplementation of the growth rate and body weight of common pheasant (Phasianus colchicus) chicks. Pol. J. Natur. Sci. 2016, 32016, 1, 363-371

21. Harrison A. P., Tygesen M. P., Sawa-Wojtanowicz B., Husted S., Tatara M. A-ketoglutarate Treatment Early in Postnatal Life Improves Bone Density in Lambs at Slaughter. Bone 2004, 35, 204-209, doi:10.1016/j.bone.2004.03.016.

22. Haugh R. R.: The Haugh Unit for measuring egg quality. US Egg Poultry Mag 1937, 43, 522-555.

23. Ipek A., Yllmaz-Dikmen B.: The relationship between growth traits and egg weight in pheasants (P. colchicus). J. Biol. Environ. Sci. 2007, 1, 117-120

24. Jones L. R., Black H. L., White C. M., Johnston N. P., McGee M. E., Donahue S. W., Egget D. L.: Effects of calcium-loading on egg production in ring-necked pheasants. J. Wildl. Manag. 2010, 74, 1295-1300, doi: 10.2193.2008-367.

25. Kirikçi K., Günlü A., Garip M.: Some quality characteristics of pheasant (Phasianus colchicus). Eggs with different shell colors. Tur. J. Vet. Anim. Sci. 2005, 29, 315-318.

26. Kokoszyński D., Bernacki Z., Korytkowska H., Wilkanowska A.: Effect of differen feeding regimens for game pheasants on carcass composition, fatty acid profile and mineral content of meat. Europ. Poul. Sci. 2014, 78, 1-10, doi: 10.1399/ eps.2014.10.

27. Kokoszyński D., Bernacki Z., Lawski K.: Quality of eggs from game pheasant fed diets of different nutritional value. Acta Sci. Pol. Zoot. 2011, 10, 41-48.

28. Kowalik S.: Relation between growth and bone collagen content in young pigs; effects of dietary $\alpha$-ketoglutarate supplementation. Bull. Vet. Inst. Pul. 2011, 55 (2), 287-292.

29. Kowalik S., Sliwa E., Tatara M. R., Krupski W., Majcher P., Studziński T. Influence of alpha-ketoglutarate on mineral density and geometrical and mechanical parameters of femora during postnatal life in piglets. Bull. Vet. Inst. Pulawy 2005, 49, 107-111.
30. Krystyniak S., Torgowski J.: The effect of two feeding systems on rearing results of pheasants (Phasianus colchicus L.) of Polish and French varieties. [in Polish] Zesz. Nauk. Przegl. Hod. 1998, 36, 201-209.

31. Li Y., Wang P., Yin J., Jin S., Su W. Tian J., Li T., Yao K.: Effects of ornithine A-ketoglutarate on growth performance and gut microbiota in a chronic oxidative stress pig model induced by D-galactose. Food \& Funct. 2020, 11, 472-482, doi: $10.1039 / \mathrm{C} 9 \mathrm{FO} 02043 \mathrm{H}$

32. Liu S., He L., Yao K.: The antioxidant function of alpha-ketoglutarate and its applications. BioMed Res. Internat. 2018, 3408467, doi: 10.1155/2018/3408467.

33. Mangiagalli M. G., Scandolara G., Marelli S. P., Giuliani M., Cavalchini L. G. Characteristics of reared game pheasant (Phasianus colchicus)'s Egg. Ital. J. Anim. Sci. 2003, 2, 115-122, doi: 10.4081/ijas.2003.115.

34. Mustonen A. M., Käkelä R., Asikainen J., Nieminen P.: Selective fatty acid mobilization from adipose tissues of the pheasant (Phasianus colchicus mongolicus) during food deprivation. Physiol. Biochem. Zool. 2009, 82, 531-540, doi: 10.1086/605393.

35. Nowaczewski S., Szablewski T., Cegielska-Radziejewska R., Kontecka H.: Egg morphometry and eggshell quality in ringnecked pheasants kept in cages. Ann. Anim. Sci. 2013, 13, 531-541, doi: 10.2478/aoas-2013-0034.

36. NRC (National Research Council). Nutrient Requirements of Poultry. $9^{\text {th }}$ ed Washington: National Academic Press. NRC. (1994). Nutrient Requirements of Poultry. Ninth Revised Edition: Subcommittee on Poultry Nutrition; Committee on Animal Nutrition, Board on Agriculture 1994, 6, 44

37. Ozbey O., Esen F., Aysondu M. H.: Effect of hatch weight on egg production, hatchability and egg quality characteristics in pheasant (Phasianus colchicus) J. Anim. Vet. Adv. 2011, 10, 3201-3206, doi: 10.3923/javaa.2011.3201.3206.

38. Paganelli C. V., Olszowka A., Ar A.: The avian egg; surface area, volume and density. Condor 1974, 76, 319-325, doi: 10.2307/1366345

39. Salim H. M., Lee H. R., Jo C., Lee S. K., Lee B. D.: Effect of sources and levels of zinc on the tissue mineral concentration and carcass quality of broilers. Avian Biol. Res. 2010, 3, 23-29, doi: 10.3184/175815510X12636595095213.

40. Šperanda M., Florijančić T., Bošković I., Bogut I., Gutzmirtl H., Grgurić D., Senčić D., Antunović Z.: The effects of organic selenium and mannan oligosaccharides on the productivity and health of pheasant chicken (Phasianus colchicus). Acta Vet. 2008, 58, 63-73, doi: 10.2298/AVB0801063S.

41. Straková E., Suchý P., Karásková K., Jámbor M., Navrátil P.: Comparison of nutritional values of pheasant and broiler chicken meats. Acta Vet. Brno 2011, 80, 373-377, doi: 10.2754/abv201180040373.

42. Suchý P., Straková E., Vitula F.: The effect of a diet supplemented with L-carnitine on egg production in pheasant (Phasianus colchicus). Czech J. An. Sci. 2008 53 (1), 31-35, doi: 10/17221/2720-CJAS.

43. Swiatkiewicz S., Arczewska-Włosek A., Józefiak D.: The efficacy of organic minerals in poultry nutrition: review and implications of recent studies. World's Poul. Sci. J. 2014, 70, 475-486, doi: 10.1017/S0043933914000531.

44. Tatara M. R., Pierzynowski S. G., Majcher P., Krupski W., Brodzki A. Studziński T.: Effect of Alpha-ketoglutarate (AKG) on mineralisation, morphology and mechanical endurance of femur and tibia in turkey. Bull. Vet. Inst. Pulawy 2004, 48, 305-309.

45. Tatara M. R., Śliwa E., Krupski W., Brodzki A., Pasternak K.: Ornithine alphaketoglutarate increases mineralization and mechanical properties of tibia in turkeys. Bone 2006, 39, 100-105, doi: 10.1016/j.bone.2005.12.016.

46. Tomaszewska E., Światkiewicz S., Archewska-Włosek A., Wojtysiak D. Dobrowolski P., Domaradzki P., Świetlicka I., Donaldsan J., Hułas-Stasiak M. Muszyński S.: Alpha-ketoglutarate: an effective feed supplement in improving bone metabolism and muscle quality of laying hens: a preliminary study. Animals 2020, 10, 2420, doi: 10.3390/ani10122420.

47. Uğurlu M., Akdă̆ F., Teke B., Salman M.: Effects of protein in diet and sex ratio on egg production, and hatching chick weight, fertility, hatchability and embryonal mortality in pheasants (Phasianus colchicus). Braz. J. Poult. Sci. 2017, 19, 231-238, doi: 10.1590/1806-9061-2016-0423.

48. Vieira S. L.: Chelated minerals for poultry. Braz. J. Poult. Sci. 2008, 10, 73-79 doi: 10.1590/S1516-635X2008000200001.

49. Wu N., Yang M., Gaur U., Xu H., Yao Y., Li D.: Alpha-ketoglutarate: physiological functions and applications. Biomolecules \& Therap. 2016 24, 1-8, doi: 10.4062 biomolther.2015.078.

50. Xiao D., Zeng L., Yao K., Kong X., Wu G., Yin Y.: The Glutamine-alphaketoglutarate $(\mathrm{AKG})$ metabolism and its nutritional implications. Amino Acids 2016, 48, 2067-2080, doi: 10.1007/s00726-016-2254-8.

51. Yamak U. S., Boz M. A., Ucar A., Sarica M., Onder H.: The effect of eggshell thickness on the hatchability of Guinea fowl and pheasants. Braz. J. Poult. Sci. 2016, 18 (spe2), 49-53, doi: 10.1590/1806-9061-2015-0214.

52. Yogi R. K., Das A., Kullu S. S., Saini M., Garg A. K., Sharma A.K.: Effect of supplementation of lutein and DL-methionine on certain haemato-biochemical parameters and serum concentration of corticosterone in captive golden pheasants (Chrysolophus pictus). Indian J. Anim. Res. 2018, 52, 242-247, doi: 10.18805/ ijar.v0i0f.3800

Coresponding autor: Assoc. Prof. Marian Flis, Akademicka 13, 20-950 Lublin, Poland; e-mail: marian.flis@up.lublin.pl 